\title{
Profile: Dr. Jane Philpott
}

\section{In conversation with Canada's new health minister}

T $\mathrm{t}$ was just an idea, a mere notion, and a crazy one at that. Maybe I should run for public office. No, she thought. Why would I do that? She was already so busy, with four children and a demanding job. Besides, the career she had, as a family doctor and medical educator, was the one she'd always wanted. It married her interest in science with her desire to help others, to serve her community.

Still, she wondered. What if politics could be a tool for doing even more? As she advanced in her medical career, she realized how difficult it was for a practising physician to address issues that profoundly influence health but can't be fixed within hospital walls. Perhaps, as a politician, she could influence health care at a higher level, fix big-picture problems, address the systemic drivers of health and wellness.

Early on the morning of Nov. 9, 2010, over coffee at The National Club in Toronto, Dr. Jane Philpott mentioned her crazy idea to someone who knew quite a bit about politics. Philpott was there for "Hot Talks," an event associated with Give a Day to World AIDS, a charity she founded in 2004 to raise money to fight HIV/AIDS in Africa. The guest speaker was Paul Martin, former prime minister of Canada. And he didn't think Philpott's idea was so crazy.

Sure, he warned her, there would be a lot of "ifs". But if she took the decision seriously, and if she could get herself nominated as a candidate in her riding, and if she could get herself elected to Parliament in a federal election, and if someday her party formed the government, and if she was given a position of influence in that government, she could accomplish so much good that it would be worth all the effort and sacrifice.

"Lo and behold, here I am today," says Philpott, laughing. "Some of those steps I didn't think would happen so quickly."

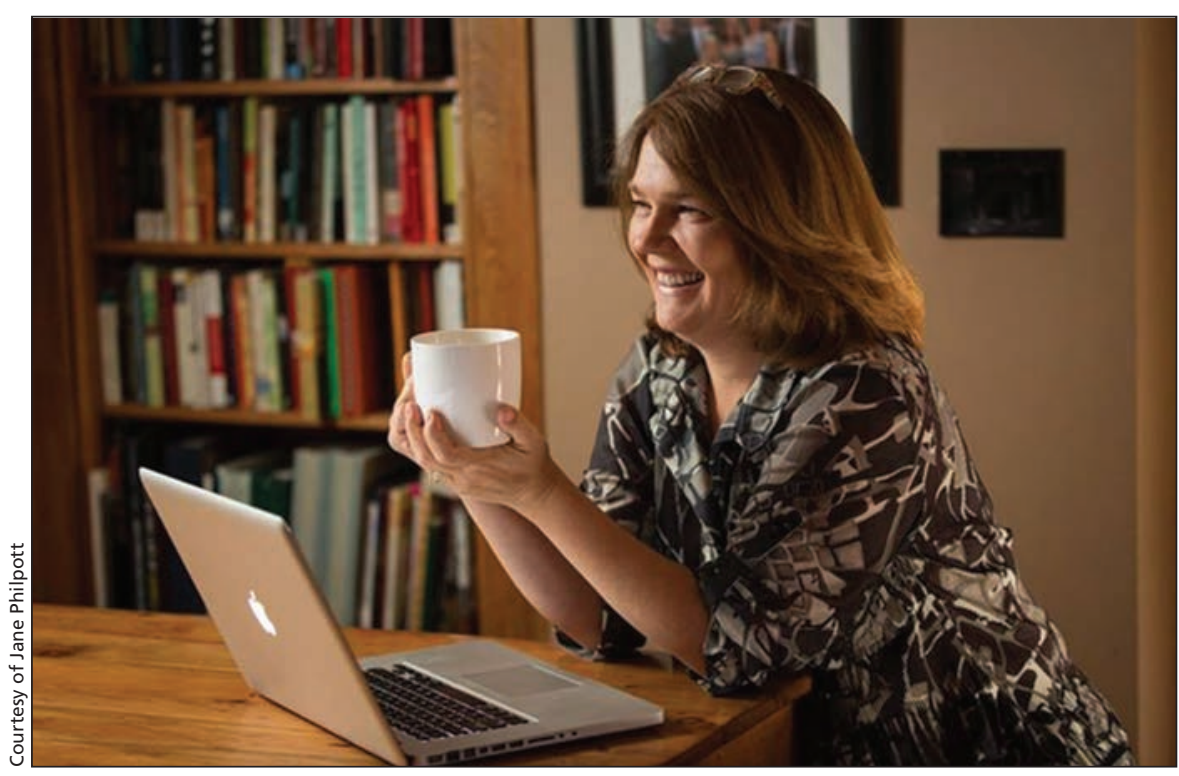

Dr. Jane Philpott: family physician, medical educator, global health advocate and, as of November 2015, Canada's federal minister of health.

On May 3, 2011, Philpott joined the Liberal Party of Canada. In the second week of September 2013, she emailed her colleagues at Markham-Stouffville Hospital to announce that she would soon be stepping down as chief of the family medicine department to seek nomination for candidacy in the next federal election. On Apr. 9, 2014, she got herself nominated as the Liberal candidate for the Ontario riding of Markham-Stouffville. On Oct. 19, 2015, she got herself elected to Parliament, and her party formed the government. Two weeks later, on Nov. 4 five years after her chat with Paul Martin, almost to the day — Philpott was sworn in as Canada's federal minister of health.

"In four years, I would like Canadians to be able to say that, as minister of health, I helped improve their lives," says Philpott. "That's the big picture."

\section{The joy of service}

The phone in the tiny kitchen rang often, day and night. Most times, Philpott recalls, it was for her father. $\mathrm{He}$ was a Presbyterian minister, and people in their town would call him for any number of reasons. Perhaps they were depressed or having marital issues. Some had just lost a loved one. Others were sick, or having money problems or just in need of conversation. In Cambridge, Ontario, like anywhere else, troubled souls were not in short supply.

Her father never complained, no matter how early or how late the phone rang. He never begrudged a request, no matter how big or how small. Often, he would stop whatever he was doing and slip out to visit the people who called, perhaps meeting them at their homes, or in a hospital or at his church. It was the same selflessness Philpott saw in her mother, a schoolteacher, who also preached the joy of serving others.

"I was raised on that value," she says. "If you have many opportunities in life, and you are born in a great country, and you get a great education, then your responsibility is to use what you have to serve others."

This was one reason Philpott would later choose to study medicine. She could have satisfied her love of science in another field, such as engineering, an option she considered. But becoming a doctor, she ultimately decided, would 
give her the most opportunities to come into direct contact with people, to address real needs, to make a real difference.

And there were few places in the world with more dire health needs than Niger Republic, the West African country where Philpott would spend much of her early career. In 1989, after training in London, Ottawa and Toronto, Philpott moved to Niger. In the past, she had completed short electives in other developing nations, including Kenya and Haiti.

"There are a lot of sobering realities you face when you work with people who, often, are desperately poor," says Philpott. "These are people who have faced incredible hardships, incredible health challenges, and would come to us with disease conditions that were almost unimaginable."

Philpott found rural Niger to be an amazing place to work, live and raise a family. At first, she practised in acute care, seeing hundreds of patients a day. She learned so much, she says, not only about medicine, but also about the people of Niger.

"It shaped me forever," says Philpott.

Sadly, however, Niger also became the place where Philpott and her family experienced a devastating personal tragedy, on Mar. 11, 1991. The worst day of her life.

\section{Overcoming tragedy}

As her two-year-old daughter's body was lowered into the stony ground outside Galmi village, in a wooden box built by a hospital carpenter, Dr. Jane Philpott prayed. If I have to return to this cemetery tomorrow and bury another daughter, I don't think I can bear it.

Just two days earlier, on a quiet Sunday afternoon, her gentle-natured daughter Emily had been jumping and splashing in a swimming pool. On Monday morning, however, Emily awoke with a fever and vomiting. By early afternoon, purple spots began appearing on her skin, and Philpott's heart sank. Her daughter, she was horrified to realize, had meningococcemia, a rapidly fatal bacterial infection.

Philpott and her husband, Pep, got into their car with Emily and their other daughter, eight-month-old Bethany. Emily needed injectable penicillin immediately; unfortunately, the hospital was two hours away. Less than half way into

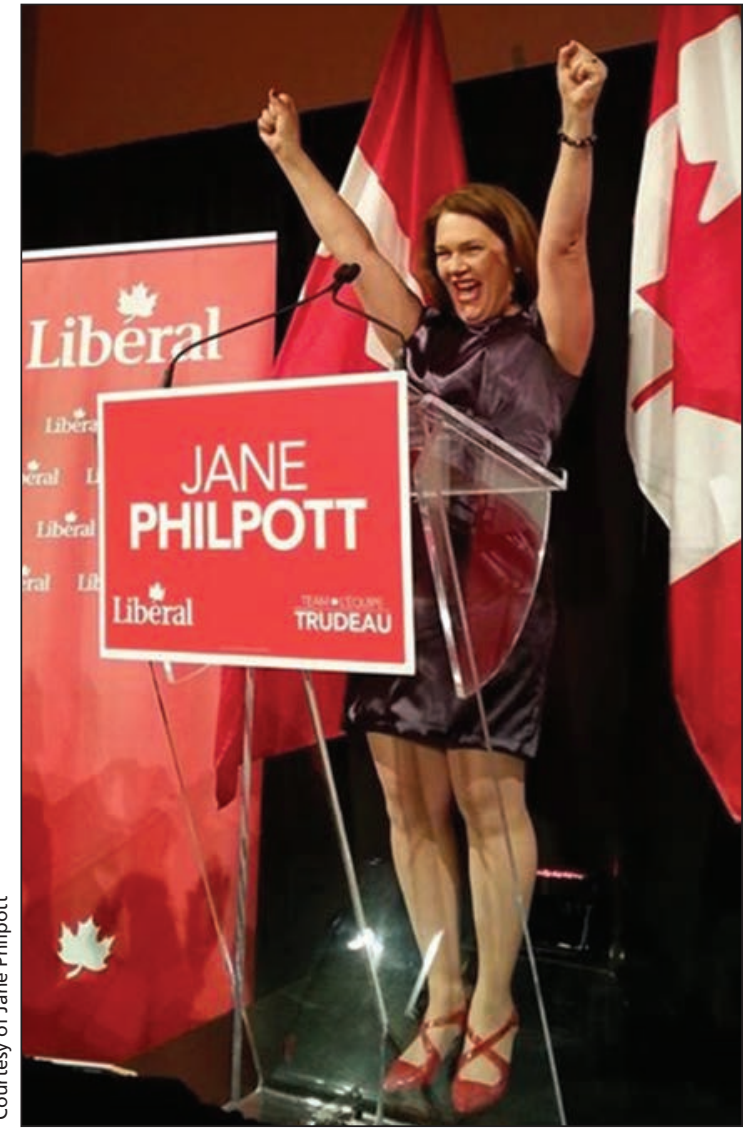

Celebrating her election night win.

their journey, Emily had a seizure and stopped breathing. As they tried to revive her, Philpott noticed there was something wrong with Bethany. A purple rash. She was also infected.

By the time they reached the hospital, Bethany's condition had worsened. Her kidneys had already failed. The doctors warned Philpott and her husband to be prepared for the worst. At Emily's funeral, the next day, they still didn't know if Bethany would survive.

But, slowly, her health improved. A pediatrician from Boston had been visiting the hospital and helped set up a pediatric intensive care unit. Bethany was given intravenous penicillin. Eventually, she was strong enough to travel to Canada to get the care she needed to fully recover.

"The very first day after Emily died, I wanted to leave the country and never come back, but very, very quickly we realized that was not what we wanted to do," says Philpott. "In a way, it would have been like her dying was for nothing, if we didn't use that experience to help inform us and to do more than we had before to help other families."

After returning to Niger, Philpott eventually moved from acute care into health education. During her last three years in the country, she worked on a project to train health workers in rural areas, finding people who, despite lacking in literacy skills, were capable and eager to learn how to help their communities.

"We taught them basic public health measures and basic treatments," says Philpott. "That was a very satisfying period of time. I got to really understand what peoples' lives were like, travelling in a four-by-four to

After three years of working in the villages, Philpott and her husband decided it was time to move back to Canada. They remote villages on a daily basis."

\footnotetext{
Timeline of Dr. Jane Philpott's education and career

1980-84 - medical school, University of Western Ontario

1984-86 - residency in family medicine, University of Ottawa/Ottawa Civic Hospital

1986-87 - tropical medicine fellowship, University of Toronto

2012 - master of public health, University of Toronto

1989-1998 - general medicine and village health worker training, Niger Republic, Africa

1998-2015 - family physician, Markham-Stouffville, Ontario

2008-2014 - chief of family medicine, Markham-Stouffville Hospital

2015-present - federal minister of health
} 
had two more children by then - both boys, Jacob and David - and finding proper schooling was proving difficult.

So in 1998, the family settled in the Ontario town of Stouffville, where Philpott would practise family medicine for more than 15 years (and have another daughter, Lydia). She would go on to lead a family health team, complete a master of public health, run a hospital family medicine department, start an HIV/AIDS charity, open a family medicine teaching unit in Markham and help a university in Ethiopia develop the country's first family medicine training program.

"There were multiple influences that were helping me to understand health care from a bigger picture," says Philpott. "How it fits into political influences. How it fits into education. And also how you can deliver really great primary care and keep your costs under control."

An incredible opportunity

She didn't want to celebrate prematurely. Yes, the numbers coming in were positive, overwhelmingly so. But she waited until late in the evening, just to be sure. When the television networks con-

\section{Excerpts from Dr. Jane Philpott's personal blog}

On public life - "As for me, I want my interaction in the public square to be marked by tolerance and respect for others."

On describing health conditions in third-world countries - "It is a grave responsibility to attempt to describe the circumstances and needs of another place in a way that is accurate, respectful and unencumbered by selfpromotion."

On public service leaders - "I want intelligent, ethical and compassionate people to take up the key roles in every political party of this country."

On cuts to refugee health care "Cuts to refugee health care are wrong from a public health perspective, an economic perspective and a moral perspective. ... A civilized society must protect its most vulnerable citizens, wherever their origin."

On running for office - "For me, a seat in the House of Commons is not a target, it's a tool. It's the tool that you and I will use to make this community better - to make this country better."

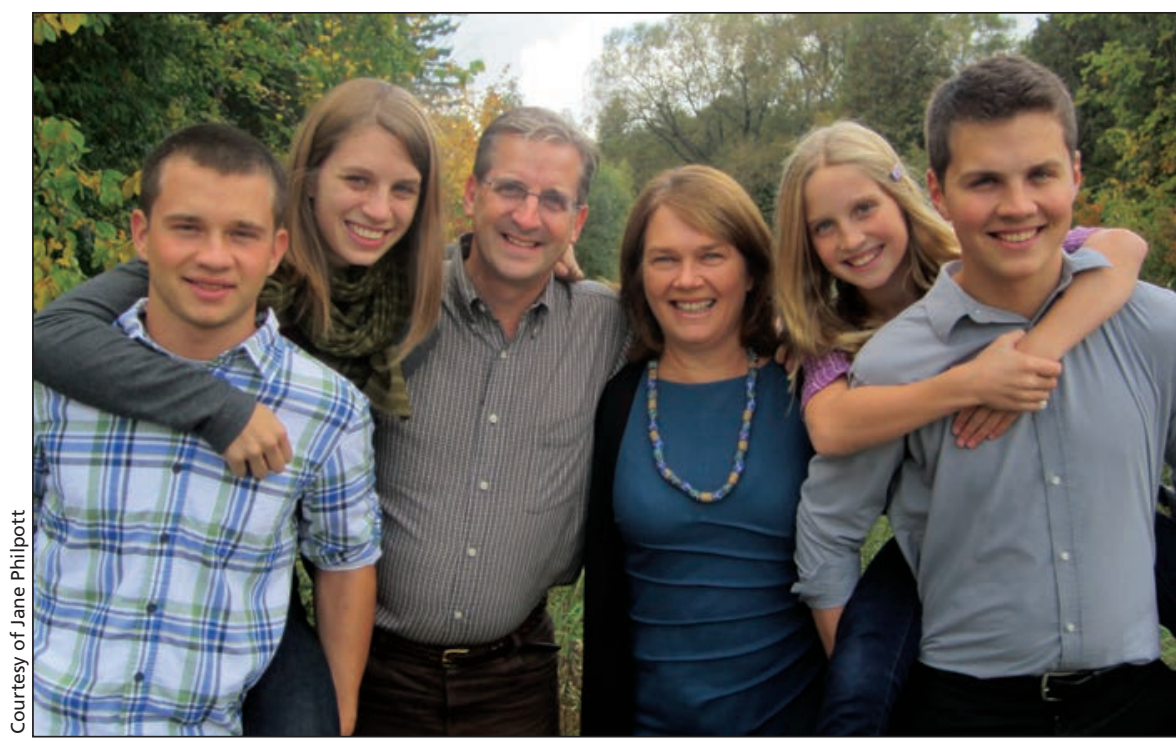

Jacob Philpott (23, flight attendant), Bethany Philpott (25, medical student), Pep Philpott (55, radio journalist), Dr. Jane Philpott (55, federal minister of health), Lydia Philpott (15, high school student) and David Philpott (21, engineering student).

firmed she had indeed won, only then did Dr. Jane Philpott allow herself to fully enjoy the moment. She was heading to Ottawa as a member of Parliament.

"It was an incredible feeling," says Philpott. "I went over to my team's party, across the street from the campaign office, and walking into that room surrounded by friends and family and volunteers was one of the happiest moments I can remember."

Not everything about politics, however, is as pleasant as a victory party. Early in her foray into public life, Philpott discovered one major difference between being a physician and being a politician: adversaries. All of her life, until that point, she had received nothing but praise when embarking on a new initiative for the public good. As a politician, she realized, that would change. There would always be opposition. There would always be people, many thousands of people, who would want her and her political party to fail.

"That's a very daunting perspective, which I had to overcome," says Philpott. "You are leaving work that is satisfying and well-remunerated and going into an environment where people won't necessarily respect you and won't be happy with some of the decisions you make."

It helps, of course, when you have family and friends to lend support. And it helps even more when one of those supporters is the prime minister of Can- ada. After the election, Philpott underwent a vetting process, so she knew she was at least being considered for cabinet. As for which position, she had no idea, not until she was led into an office in Ottawa and, during a "pleasant and lovely conversation" with Prime Minster Justin Trudeau, was asked to serve as the minister of health.

"It was an overwhelming moment," says Philpott. "I felt so incredibly honoured to be asked to do this, and humbled that he and his team felt I could do it."

She acknowledges it is a "daunting task" to lead the ministry of health, and that she has much to learn, but Philpott is looking forward to working with her team to improve health care for Canadians. She is excited to begin negotiations on a new health accord, and to rebuilding relationships with provinces and territories that have deteriorated because "we have lacked federal leadership on health care in the last decade." Other specific goals include improving home care, addressing gaps in mental health services and making pharmaceuticals more accessible and affordable.

"It's an incredible opportunity," says Philpott. "All of those conversations I've had in recent years about how to do better for Canadians - I'm now able to put those ideas to work." — Roger Collier, CMAJ

CMAJ 2016. DOI:10.1503/cmaj.109-5214 